\title{
PRUDENCE AND CONSTITUTIONAL RIGHTS
}

\author{
EDWARD F. MCCLENNEN ${ }^{\dagger}$
}

[T] he object of man's desire is not to enjoy once only and for one instant of time, but to assure forever the way of his future desires. And therefore the voluntary actions and inclinations of all men tend not only to the procuring, but also to the assuring of a contented life. ${ }^{1}$

\section{INTRODUCTION}

A great deal of historical and contemporary work in the economic theory of institutions has focused on what the representative person can expect in the way of economic benefits by participating in various institutional arrangements. Starting with Adam Smith, and running like a bright thread throughout virtually all the subsequent theoretical literature on political economy, one can mark a preoccupation with the conditions under which individuals can transact with one another to their mutual expected economic gain." In the more formal literature on welfare economics, this concern culminates, in the middle of the twentieth century, in a fundamental theorem, according to which individuals can, under conditions of perfect competition, achieve an outcome that is Pareto-optimal and Pareto-efficient relative to the outcome in which no transactions take place. ${ }^{3}$ The theme of Paretoefficient changes in institutional structures is also central to many other contemporary works, including Coase's analysis of the firm and

${ }^{\dagger}$ Centennial Professor of Philosophy, Logic and Scientific Method, London School of Economics.

Thomas Hobbes, LeViathan ch. xi, para. 1 (A.P. Martinich ed., Broadview Press 2002) (1651).

${ }^{2}$ Of special historical note here are the discussions in JOHN LOCKE, THE SECOND TREATISE OF Government ch. ix, paras. 25-50 (Thomas P. Peardon ed., MacMillan Pub. Co. 1952) (1690), of the advantages of a system of property, Hume's discussion of justice in 2 David Hume, A Treatise of Human Nature bk. III, pt. II, $\$ \S$ i-iv (T.H. Green \& T.H. Grose eds., Longmans, Green \& Co. 1890) (1739), and Smith's argument for markets in ADAM SMITH, AN INQUIRY INTO THE NATURE AND CAUSES OF THE WEALTH OF NATIONS (James E. Thorold Rogers ed., Clarendon Press 1880) (1776).

${ }^{3}$ Formal presentations of these results are to be found in, for example, K.J. ARROW \& F.H. HAHN, GENERAL EQUIlibrium ANALYSIS (1971); G. DEBREU, THEORY OF VALUE (1959). 
the problem of social cost, ${ }^{4}$ Posner's economic analysis of law, ${ }^{5}$ Axelrod's work on iterated prisoner's dilemma games, ' Ullmann-Margalit's study of the emergence of norms, ${ }^{7}$ and the whole of the public choice literature of the last four decades. ${ }^{8}$ The Pareto conditions also figure centrally in virtually all axiomatic bargaining and social choice models.' In all of this work, the explicit or implicit claim is that rational individuals, when confronted with the possibilities for mutual (expected) economic gain, will be disposed to take the steps necessary to secure such gains.

People typically are concerned, however, not just to maximize expected economic gains, but also to protect themselves against losses that would compromise their prospects for future gains. In the language of Hobbes, as quoted above, they are interested not only in procuring but also in assuring. ${ }^{10}$ The latter theme reappears repeatedly in the history of political theory, " and especially in the literature dealing with constitutional restraints on the exercise of both legislative and executive power. ${ }^{12}$

${ }^{4}$ R.H. Coase, The Nature of the Firm, 4 ECONomiCA 386 (1937); R.H. Coase, The Problem of Social Cost, 3 J.L. \& ECON. 1 (1960).

5 Richard A. POSNer, ECONOMiC ANALySis of LAW (3d. ed. 1986).

${ }^{6}$ Robert AxElrod, THe Evolution of CoOplration (1984).

${ }^{7}$ Edna UllmanN-Margalit, THE EmERGenCe OF NoRms (1978).

${ }^{8}$ For a recent overview and extensive bibliography on the public choice tradition, see Dennis C. Mueller, Public ChOICE III (2003).

${ }^{9}$ Such bargaining models are detailed in R. DUNCAN LUCE \& HOWARD RaIfFa, GAMEs AND DECISIONS: INTRODUCTION AND CRITICAL SURVEY 114-54 (1957); ALVIN E. ROTH, GaMe THEORETIC MOdEls OF BARGaINING (1985). The social choice models are the focus of attention in KENNETH J. ARROW, SOCIAL CHOICE AND INDIVIDUAL Values (1951); Amariya K. Sen, Collective Choice and Social Welfare (1970).

${ }^{10}$ This theme is struck not only in the quotation given above from Hobbes's Leviathan, but in his remark that the "passions that incline men to peace are fear of death, desire of such things as are necessary to commodious living, and a hope by their industry to obtain them." HOBBES, supra note 1 , at ch. xiii, para. 14.

"In early Enlightenment discussions, it is reflected, among other places, in Locke's discussion of the right of rebellion against tyrranical acts of the government, a right that does not receive recognition in Hobbes's Leviathan. Compare LOCKE, supra note 2, at chs. xvii-xix (considering the extent of the right to oppose "unjust and unlawful force"), with HOBBES, supra note 1, at ch. xviii, para. 3 ("[T] hat they are subjects to a monarch [means that they] cannot without his leave cast off monarchy and return to the confusion of a disunited multitude ....").

${ }^{12}$ The relevant literature in legal theory here is, of course, vast. David Richards provides a useful survey of this perspective within the context of U.S. constitutional theory and interpretation. DAVID A.J. RICHARIS, FOUNDATIONS OF AMERICAN CONSTITUTIONALISM 18-130 (1989). James Buchanan has argued the case for the importance of constitutional constraints. JAMES M. BUCHANAN, THE LimITS OF LIBERTY: BETWEEN ANARCHY AND LEVIATHAN (1975). Surprisingly, however, few contemporary 
philosophers have ventured very far into this area. Two very notable exceptions are David Wiggins, Claims of Need, in Needs, Values, TruTh 1 (Oxford Univ. Press 3d ed. 1998) (1987); Ronald Dworkin, What Is Equality? Part 2: Equality of Resources, 10 PHIL. \& PuB. AFF. 283 (1981). Dworkin's remarks about prudential considerations occur in the context of an exceedingly careful but very complex discussion of the issue of equality of resources. Id. at 292-304. In the development of his main thesis regarding equality of resources, Dworkin utilizes the idea of a model world in which all start out with equal resources (in the form of an equal number of clamshells) which can be used to bid, in a grand auction, for various goods and services that the participants desire. Among other goods that are available in this way are insurance policies, which insure against various kinds of "bad" luck. If (1) one could assume that everyone had an equal risk of suffering some catastrophe, (2) at the time of the auction, no one yet knew what catastrophes would befall them, and, finally, (3) persons had different attitudes toward risk-some being more risk prone and others less-then one might think it fair to let losses fall where they may, and not redistribute resources after the fact so as to compensate those who suffer catastrophes. Id. That is, the idea would be that individuals are to make their own decisions as to just how much insurance they will purchase. In an interesting move, however, Dworkin argues that (2) obviously fails to hold in any real world. That is, "[s]ome people are born with handicaps, or develop them before they have either sufficient knowledge or funds to insure on their own behalf." Id. at 297. This leads Dworkin to propose the idea of a "hypothetical" insurance market, in which one seeks to determine how much insurance coverage the "average" member of the community would purchase, and then compensates those who suffer disasters out of "some fund collected by taxation or other compulsory processes but designed to match the fund that would have been provided through premiums if the odds had been equal." Id. at 298. The argument is further elaborated-to deal with the fact that (1) is also not the case, that all do not really face equal risks, and that one might want to move beyond the idea of setting the public compensation in terms of the private compensation provided by the amount of insurance the average person would purchase, but the net effect is an argument for supplementing "private" auctions (the market) with a public insurance scheme. Id. at 300-09. Dworkin's whole approach, moreover, essentially rests on a tacit appeal to "common intuitions" rather than considerations of rational choice. Such an appeal constitutes what R.M. Hare characterizes as a Cartesian approach, in which one tries to deduce particular rights and duties from self-evident first principles of morality. See R.M. HARE, THE LANGUAGE OF MORALS 32-44 (1952) (providing a convincing critique of the appeal to self-evident truths in the case of moral principles). The approach is first subjected to withering criticism in Locke's Essay Concerning Human Understanding, as part of his rejection of the Thomist view of the status of "practical" principles. See JOHN LOCKE, 1 AN ESSAY CONCERNING HUMAN UNDERSTANDING ch. iii. Wiggins's explorations are occasioned by the following remark, taken from an article by H.L.A. Hart:

A concept of legal rights limited to those cases where the law ... respects the choice of individuals would be too narrow. For there is a form of the moral criticism of law which ... is inspired by regard for the needs of individuals for certain fundamental freedoms and protections or benefits.

H.L.A. Hart, Bentham on Legal Rights, in 2 OXFORD ESSAYS IN JURISPRUDENCE 171, 200 (A.W.B. Simpson ed., 1973). The substantive position that Wiggins articulates is very close, I think, to the one that I try to develop here. We differ principally in regard to how such a view is to be defended. In particular, Wiggins rejects the idea of grounding rights in purely prudential or rational considerations. WIGGINS, supra, at 35-37. In place of this, Wiggins appeals to what he presumably takes to be "common intuitions," an appeal that, once again, following Locke and Hare, I find most unsatisfactory. The 
These two concerns, regarding economic gain and protection against loss, each play a role in James Buchanan and Gordon Tullock's landmark work, The Calculus of Consent. ${ }^{13}$ Considerations of protection against losses favor the adoption of a unanimity rule in which each individual's consent must be given to reach a collective decision, since under such a rule you can veto any policy that would impose losses on you. Buchanan and Tullock argue, however, that operating under an unanimity rule is very costly, not only in terms of the time and other resources that must be expended to secure a full consensus, but in terms of opportunity costs. ${ }^{14}$ Many valuable projects will not be ratified and implemented because of the refusal of some to give their assent. If these decision-making costs are sufficiently high, one will find it in one's interest to support less-than-unanimity voting rules. The significant savings in decision-making and opportunity costsand hence resultant economic gains-will justify exposing oneself to the risk of policies that can impose losses upon oneself. Indeed, in certain cases, the most cost-effective approach will be to allow decisions to be made by a simple majority vote, or even to be settled by an administrative decision. ${ }^{15}$

other major difference is that Wiggins, while recognizing the place of "publicly provided systems of education, legal aid and basic health care," id. at 36 , gives priority of place to rights "securing individuals from arbitrary arrest, imprisonment or punishment, and assuring them of other civic and legal protections," as well as the "right to make certain sorts of agreement with other individuals, to buy the necessities of life, sell the product of one's labour, and be not dispossessed of that which one has appropriated or mixed one's labour with in ways seen as worthy of being accorded legal recognition." Id. at 34 . The priority claim is, however, merely asserted and not defended.

${ }^{13}$ James M. Buchanan \& GoRdon Tullock, The Calculus of Consent: LOGICAL FOUNDATIONS OF CONSTITUTIONAL DEMOCRACY (1962).

${ }^{14}$ See id. at 63-84 (recognizing that costs depend on the decisions to be made and analyzing those costs).

${ }^{15}$ Their key argument here, it should be noted, explicitly invokes the concept of uncertainty:

Essential to the analysis is the presumption that the individual is uncertain as to what his own precise role will be in any one of a whole chain of later collective choices that will actually have to be made. For this reason he is considered not to have a particular and distinguishable interest separate and apart from his fellows. This is not to suggest that he will act contrary to his own interests; but the individual will not find it advantageous to vote for rules that may promote sectional, class, or group interests because, by presupposition, he is unable to predict the role that he will be playing in the actual collective decision-making process at any particular time in the future. He cannot predict with any degree of certainty whether he is more likely to be in a winning or a losing coalition on any specific issue. Therefore, he will assume that occasionally he will be in one group and occasionally in the other. His own self-interest will lead him to choose rules that will maximize the utility of an 
Buchanan and Tullock go on to argue, however, that it is also rational for individuals to insist on a constitution that specifies different decision-making rules for different classes of policy matters. ${ }^{16}$ The rational individual may well be willing to support a simple majoritarian rule (or even administrative choices) for cases in which substantial issues are not at stake, but insist on something more approximating a rule of unanimity for cases where the costs of an adverse decision could turn out to be prohibitively high. In that latter category, they suggest, will be policy decisions that modify or restrict the structure of individual human and property rights.

The relevant point is that the individual will foresee that collective action in this area may possibly impose very severe costs on him. In such cases he will tend to place a high value on the attainment of his consent, and he may be quite willing to undergo substantial decision-making costs in order to insure that he will, in fact, be reasonably protected against confiscation.

The argument for majoritarian procedures and administrative choices pivots, then, on considerations of the expected savings from what would be the high decision costs associated with the unanimity rule. But the argument for constitutional restrictions, for a "bill of rights," pivots on a different consideration altogether-on the concern of how to avoid substantial losses that could flow from allowing the majority (or governmental administrators) to settle all issues.

While discussion of the reduction of costs argument spans virtually the whole of The Calculus of Consent, the argument for protection against substantial losses receives only a few paragraphs of attention. In what is to follow, I shall try to redress this imbalance by exploring

individual in a series of collective decisions with his own preferences on the separate issues being more or less randomly distributed.

$I d$. at 78. It is also important to note that the degree of uncertainty invoked here is considerably less than that invoked by John Rawls in his famous "behind the veil of ignorance" argument. See JOHN RAWLS, A THEORY OF JUSTICE 17-22 (1971) (discussing a theory of justice as an alternative to utilitarianism). In Rawls's construction, participants must make a decision about principles under conditions of radical uncertainty, in which they know nothing about the position into which they were born in society and what talents and abilities they have; indeed, they are even denied knowledge of their own conceptions of the good, of what is ultimately valuable. Id. Moreover, their uncertainties about all these things are so great as to make it inappropriate to assign probabilities to various possibilities. For Buchanan and Tullock, on the contrary, participants face only ordinary uncertainties about the future, and, as the above quote makes clear, it is appropriate for them to think in terms of there being a uniform probability distribution over the relevant space of possibilities.

${ }^{16}$ BUCHANAN \& TULLOCK, supra note 13 , at 81 .

${ }^{17}$ Id. at $73-74$. 
the protection argument at length. I also want to extend Buchanan and Tullock's brief argument in two respects: First, by way of offering a grounding for their important insight, I shall argue that the concern to protect against losses that would impair the continued pursuit of one's ongoing and future interests is a matter of prudence ${ }^{18}$ and, as such, is something that can plausibly be viewed as a rational concern, at least for most persons. Second, I shall argue that the objects of such a prudential concern appropriately include not just the kinds of protections enumerated, for example, in the U.S. Bill of Rights, ${ }^{19}$ but other rights as well, including welfare, health, legal representation, and educational rights. That is, I shall argue that prudential considerations provide a powerful argument not only for constitutional restrictions on governmental actions, but constitutionally mandated, positive government programs as well. On this way of thinking, a wide spectrum of public programs can be best understood as efficient ways in which persons can be provided with insurance against the vicissitudes of both social and commercial activities as well as natural events. Within the context of a theory of prudential concerns, then, the view that government is best when it governs least is very questionable.

\section{Characterizing Prudential Motivation}

To be prudent is clearly something distinct from, say, simply to have concern for long-term as opposed to short-term considerations. One who focuses on long-term investments, but chooses among alternatives simply by reference to expected monetary return, is not thereby being prudent. The plan that yields the greatest expected monetary return might expose one to substantial risk, including loss of all of one's capital. To choose in this manner is not to choose prudently. Being prudent involves giving special consideration to the avoidance of at least certain kinds of loss, even if the loss in question is quite unlikely.

${ }^{18}$ The Oxford English Dictionary (OED) defines prudence as "the ability to discern the most suitable, politic, or profitable course of action, esp. as regards conduct; practical wisdom, discretion.” OXFORD ENGLISH DICTIONARY 728 (2d ed. 1989). But other definitions, see, e.g., WEBSTER'S NEW WORLD DICTIONARY 601 (2d ed. 1979), include the idea of "careful management." This latter sense is the one in which I am interested. The wide and somewhat erratic range of connotations for the term renders the history of the concept not very helpful for my purposes. Suffice it to say that what I shall call "prudence" is clearly one of the things that was traditionally associated with this term.

${ }^{19}$ U.S. CONST. amends. I-X. 
Being concerned with avoiding loss, however, still does not capture precisely enough the idea of prudence. If one had a steady and guaranteed source of income, one that was more than sufficient for the promotion of one's projects-so that what is lost is easily replaceable-avoiding loss would hardly be dictated by prudence. Prudence is a more focused concern than just avoiding loss, even substantial loss. It is better characterized as a concern about avoiding a loss that would be disastrous for the individual in question-and that involves great harm or damage to that person. This usually includes loss of life, serious impairment of health, loss of income, and substantial loss of property. In very general terms, it is concern to avoid a loss that would prove ruinous to substantial and important undertakings. ${ }^{20}$

Since disaster is often relative to specific projects that can vary significantly from one person to the next, it might seem hard to draw any general conclusions about what prudence specifically requires. But the references to loss of life and impairment of health make it clear that there are some important general conclusions that can be drawn. While projects will vary from one person to the next, it is plausible that each will still be disposed to avoid substantial losses with regard to what have come to be known as "primary goods." ${ }^{21}$ These are goods that are typically useful regardless of one's plan of life or particular undertakings. ${ }^{22}$ They include one's physical, emotional, and intellectual capabilities or skills; financial and other (renewable or nonconsumable) resources; and opportunities-all of which play a critical role in the pursuit of one's projects.

Primary goods are instrumental goods, but they have a special place in a system of instrumental value. The value of an instrumental good is often taken to be entirely derivative of, and dependent upon, the value of that to which it is a means. From this perspective, usefulness is an ephemeral value, likely to disappear when one's interest in

${ }^{20}$ The $O E D$ defines disaster as "anything that befalls of ruinous or distressing nature; a sudden or great misfortune, mishap, or misadventure; a calamity." OXFORD ENGLISH DICTIONARY, supra note 18, at 723.

${ }^{21}$ John Rawls introduced the term. RAWLS, supra note 15, at 62 . He divided such goods into two groups, social and natural. Social primary goods include rights and liberties, powers and opportunities, income and wealth, and self-respect. Natural primary goods include health and vigor, intelligence, and imagination. Id. at 53-54.

${ }^{22}$ As Rawls puts the idea in A Theory of Justice, "with more of these, men can generally be assured of greater success in carrying out their intentions and advancing their ends." $I d$. at 92. 
the end to be served thereby is altered. ${ }^{23}$ But primary goods have a value that tends to be conserved in the face of such changing interests, for they are instrumental to a significantly wide range of projects that persons might pursue. Correspondingly, the loss of such a good can compromise many goals or ends that a given person has or might have in the future.

One can think of a primary good as having, then, a focal value, by virtue of its having a special instrumental place at the intersection of many goals and projects. The focal significance of such goods is even more pronounced within the context of ongoing, longer-range activities. In this case, the securing of such a good can become critical to the success of whole sequences or chains of actions, spreading from the present into the distant future. In the language familiar to those engaged in commercial and productive activities, the temporal span of plans creates a problem of scheduling. Failure to provide for projects to be undertaken tomorrow can deeply compromise those future projects. So one's task is perpetually to plan today for what will be needed tomorrow.

This is the case even if one is completely certain, at each point in time, as to how the success or failure of future activities will be affected by one's own activities and various background events. But the temporal span and problem of scheduling it poses takes on a special significance by virtue of the uncertainty that typically attends such planning. Such uncertainty arises at two different levels: First, one has to make plans and begin projects with very imperfect information about the likelihood of events that can radically affect success or failure. Second, one cannot be sure, at any given moment, what one's goals and interests will be in the (more distant) future. In the face of such uncertainties, a focus on primary goods is to be expected, since these are goods that are important to secure and conserve regardless of what the future brings. For all these reasons, the value of a primary good tends to remain stable even against the background of changing conditions, interests, and projects, and hence even against changing views of what is intrinsically valuable.

${ }^{23}$ For instance, the possession of a set of excellent knives is of extraordinary value to a dedicated chef, but not of much value to one whose lifestyle involves eating out most of the time. 


\section{A. Risks Involving the Loss of Primary Goods}

In what is to follow, I shall concentrate on substantial losses that pertain to such special, all-purpose goods. Whatever other goods are also the objects of prudential concern, the substantial loss of primary goods will compromise or impair one's ability to pursue continuing or anticipated projects, and this is a matter of prudential concern. It is commonplace, of course, that a rational approach to deliberation involves being prepared to look at net gains and losses. As the argument for less-than-unanimity rules suggests, one can often treat losses as tolerable if they are balanced out against sufficient gains (e.g., cost reductions). But there are special considerations that arise regarding deliberation in contexts in which one could experience a substantial loss of some primary good. Since it is the carrier of focal value, its loss is something that affects a whole range of one's interests. ${ }^{24}$ This means that one will typically have an aversion to its loss that can only be allayed, if at all, by a promise of a significant compensating gain of other goods. Other things being equal, aversion to the loss of primary goods, then, leads to a disposition to conserve them-to assure oneself a steady supply of resources with which to pursue not just present, but future projects as well. Alternatively put, persons will be more likely to invest resources to protect themselves against such losses. Such an investment can take the form of avoiding dangerous situations, of entering into cooperative relations with others to prevent or reduce the adverse impact of such situations, or of purchasing insurance that will compensate for such unavoidable damages. And such an investment tends to be a feature of what the representative individual regards as a rational approach to planning. ${ }^{25}$

${ }^{24}$ Employing the framework used in DAVID BRAYBroOKE, MEETING NEEDS 29-32 (1987), we can describe such concerns as focusing on "course-of-life" needs as distinguished from adventitious needs, which relate to very specific projects, such as the need for a spinnaker if one is to be competitive in a sailboat race.

${ }^{25}$ This is not to say that the deliberation of a rational individual focuses only on the conservation of primary goods. Any good to which one attaches great intrinsic value, particularly one that is irreplaceable, is something that one will be disposed to conserve. Again, if a person's whole life were bound up with a specific, overriding project-say the completion of a major bibliography-a considerable focus of one's prudential concern specifically will be the preservation of the entries one has already complied, and this may call for very specific investments, e.g., back-up discs stored in fireproof containers, of a sort that might well have little value with respect to any other project one might pursue. But for most persons prudential concerns will, in a wide range of situations, tend to focus on all-purpose goods-on resources that characteristically can and will be put to alternative uses. 


\section{B. Prudence and Rationality}

Is prudence mandated by rationality? Clearly, there are life projects that require one to expose oneself to great risks. Those who dedicate themselves to furthering some grand ideal may be fully and appropriately prepared to sacrifice themselves, their health, and their personal well-being, for the sake of that ideal. At the other end of the spectrum, it is possible to imagine persons whose self-consciouslychosen lifestyle involves paying little or no attention to assuring the satisfaction of future desires; they simply prefer living by their wits, moment to moment, with little concern for the future. It would be a mistake, then, to simply incorporate the idea of prudence into that of rationality. We can accept the idea that for some individuals certain prudential concerns will be very attenuated, or perhaps even nonexistent. And in special cases there may not be any rational ground on which to criticize the person for not having such concerns.

But it is still the case that for the vast majority of persons, with quite disparate goals and interests, a prudential concern is not simply just one concern among many that such persons might just happen to have. It is a concern that naturally and unavoidably arises within the context of ordinary deliberations about organizing activities in pursuit of one's present and anticipated interests. Other things being equal, if it is rational to choose to effectively promote our ends, and if we now have longer-range interests and/or expect to have interests that we will want to pursue in the future, then it is rational to make provisions to ensure that our ends can be satisfactorily achieved. For most individuals, then, some measure of concern for prudential considerations will be a feature of rational deliberation.

\section{Prudence and Expected Utility Theory}

I have suggested above that concerns regarding risk and uncertainty cannot be met by simply choosing to maximize expected monetary or economic return. A high-expected economic return is compatible with risking all of one's resources (including one's life) so long as the probability of such a loss is sufficiently small. In the face of uncertainties about natural events and the behavior of other participants, prudent persons will likely forego a certain amount of expected gains in order to protect themselves against the possibility of disastrous losses. By purchasing insurance, for example, one can reduce significantly the probability of certain losses, but paying the required 
insurance premium will mean that one's expected monetary return is reduced. $^{26}$

The standard theory of rational choice is less than fully satisfactory in the way in which it deals with such prudential concerns. In the landmark work in the second half of the twentieth century on the formal representation of preferences through utility functions, The Utility Analysis of Choices Involving Risk, room is made in principle for capturing prudential concerns. ${ }^{27}$ That is, utility theory allows for risk and uncertainty aversion (or preference). The way this is done is rather complicated, however, and quite counterintuitive. Instead of thinking, as in the case of time discounts, of a fractional discount factor that might vary from one person to the next, it is assumed that all rational agents discount risky prospects at the same fractional value that represents the (subjectively or objectively defined) probabilities of the various gains and losses. Risk aversion or risk seeking is then quantified by encoding it in the marginal rates of change in the utility values of increasing amounts of some nonrisky good. This is expressed by the degree of concavity or convexity of the utility function for increasing amounts of the particular good in question. ${ }^{28}$ Whatever is gained thereby in terms of an elegant axiomatization of utility, this method of representing attitudes toward risk has created great conceptual confusion. It seriously conflates two very distinct conceptsthat of attitudes toward risk and that of decreasing (or increasing) marginal rates for increasing amounts of the good in question. It also severely restricts how attitudes toward risk can be incorporated into one's utility function. ${ }^{29}$

The story concerning uncertainty, as distinct from risk, is more complicated. Intuitively, uncertainty involves disjunctively possible outcomes for which one cannot assign any determinate probability values. $^{30}$ In the standard "Bayesian" (or "personalist") construction of utility and risk, however, uncertainty is quite implausibly and counterintuitively reduced to a form of risk. Under the Bayesian construc-

${ }^{26}$ See, e.g., Milton Friedman \& Leonard J. Savage, The Utility Analysis of Choices Involving Risk, $56 \mathrm{~J}$. POL. ECON. 279, 279 (1948) (characterizing the purchase of insurance as "choosing certainty in preference to uncertainty").

${ }_{28}^{27}$ Id. (describing degrees of risk in a broad range of economic choices).

${ }^{28}$ See, e.g., John W. Pratt, Risk Aversion in the Small and in the Large, 32 ECONOMETRICA 122 (1964) (discussing a measure of risk aversion).

${ }^{29}$ For an extended discussion of the problems here, see EDWARD F. MCCLENNEN, RATIONALITY AND DYNAMIC CHOICE: FOUNDATIONAL EXPLORATIONS 4459 (1990).

${ }^{30}$ For the classic statement of this view, see R. DUNCAN LUCE \& HOWARD RAIFFA, GAMES AND DECISIONS: INTRODUCTION AND CRITICAL SURVEY 275-326 (1957). 
tion, it is assumed that a rational agent, who is completely uncertain about the probabilities to be assigned to each of $n$ mutually exclusive and exhaustive events, will treat such events as equally likely. That is, she will assign $1 / n$ to each of the $n$ events." This leaves no room for the plausible notion that uncertainty can engender special concerns over and above those of risk, where probabilities are well defined. ${ }^{32}$ Leaving that issue aside, however, it is important to note that by reducing uncertainty to risk and permitting different attitudes toward risk, the Bayesian construction also permits variation in attitude toward uncertainty from one person to the next.

\section{The Objects of Prudentlal Concern}

I have already noted that human projects are sufficiently diverse that there is perhaps nothing the loss of which would compromise any project that a given person might pursue. If one's ultimate and overiding project is to set oneself afire and thereby sacrifice one's life in protest of some injustice done to some group of persons, one's prudential considerations will be vastly more focused and narrower than those of the "ordinary" person. Therefore, we will have to settle for delineating attributes that tend to be indispensable or important for a significantly wide range of human pursuits.

Another complication is that anything that one might want to characterize as a proper object of prudential concern could also be something a given individual regards as intrinsically valuable. It is well documented that many things that persons initially value simply for their usefulness end up being treated as having special intrinsic value. ${ }^{33}$ This tendency poses a major problem for any inquiry such as the present, which seeks to ground the value of various institutional structures in their capacity to promote human interests. Since individuals will find such institutions intrinsically valuable, much of what I will argue will appear unnecessary, as superfluous, given the individual's own value commitments. I can only hope that readers will still appreciate that there are some individuals for whom these institutional structures are more problematic, and that my arguments re-

${ }^{31}$ Id. at 286-98; see also LeONARD J. SAVAGE, THE Foundations of STATISTICS 45 (2d rev. ed. 1972) (presenting Bayes's rule).

32. The opening shot, and in many respects still the most compelling presentation of the case against this way of thinking about uncertainty, is found in Daniel Ellsberg, Risk, Ambiguity and the Savage Axioms, 75 Q.J. ECON. 643 (1961).

${ }^{33}$ One of the most insightful treatments of this phenomenon is found in WILLIAM H. GASS, FICTION AND THE FIGURES OF LIFE 191 (1971). 
garding the usefulness of those structures may have significant leverage with them.

One must also recognize that responding to a particular prudential concern will typically involve making a commitment to a variety of different policies. For example, if one is deeply concerned with maintaining one's bodily integrity and health, one will be concerned not only with protecting oneself from various diseases, but also from criminal attacks by others, from drunk drivers, from a wide variety of natural disasters such as storms and floods, and from the actions of overzealous public prosecutors and police officers. As we shall see shortly, the story to be told here is complicated.

Against the background of these rather general observations, there are a number of ways in which one might classify prudential concerns relating to primary goods. The approach I shall use is to divide them into four categories: bodily integrity, mental and emotional integrity, various kinds of resources, and opportunities.

\section{A. Bodily Integrity}

For most undertakings, maintenance of one's physical existence as a living, functioning organism is essential. ${ }^{34}$ Under the general heading of bodily integrity one can include not just the integrity of the body (such as maintenance of life, limb, and health), but also maintenance of natural and acquired physical skills, attributes, and abilities. This means, among other things, that one will not only be concerned with protection against physical damage to the body, but also with the provision of adequate food, water, clothing, shelter, exercise, and rest.

\section{B. Mental and Emotional Integrity}

The question of what it means to function well at this level is subject to somewhat more debate, but viewed from the perspective of a theory of primary goods, one's ability to function well both mentally and emotionally is essential to virtually any undertaking. Functioning well at this level involves the development of various mental and emotional skills, including being able to deliberate and reason well, and being able to be "in control of," rather than being driven by, one's

34 Typically, but not invariably, loss of life, limb, and health will deeply compromise one's undertakings regardless of what they are. But if one's objective is to make a martyr of oneself, sacrificing one's life will be an essential part of what one plans to accomplish. 
emotions. A plausible case can be made, however, that this also involves assurances of some of the classical "freedoms" cited in the U.S. Bill of Rights: freedom of thought and conscience; ${ }^{85}$ protection against arbitrary interference with one's privacy, family, home, and correspondence; ${ }^{36}$ and freedom from harassment and continual threats. ${ }^{37}$ In addition, one can argue that this category also includes: protection of one's honor and reputation; access to familial and love relations; friendships, cultural and religious ties; and maintenance of conditions under which one can achieve self-respect, including meaningful work, acceptance, and recognition by others. ${ }^{38}$

${ }^{85}$ See U.S. CoNST. amend. I ("Congress shall make no law respecting an establishment of religion, or prohibiting the free exercise thereof ....”); Lee v. Weisman, 505 U.S. 577, 591-92 (1992) (holding that the First Amendment prohibits "[a] state-created orthodoxy [that] puts at grave risk that freedom of belief and conscience"); Wooley v. Maynard, 430 U.S. 705, 714 (1977) ("[T] he right of freedom of thought [is] protected by the First Amendment.").

${ }^{30}$ See U.S. CONST. amend. IV ("The right of the people to be secure in their persons, houses, papers, and effects, against unreasonable searches and seizures, shall not be violated ...."); U.S. CONST. amend. V ("No person shall . . . be deprived of life, liberty, or property, without due process of law."); U.S. CONST. amend. XIV ("[N] or shall any state deprive any person of life, liberty, or property, without due process of law."); see also California v. Hodari, 499 U.S. 621, 646 n.18 (1991) ("The purpose of the Fourth Amendment is " to prevent arbitrary ... interference by [law] enforcement officials with the privacy and personal security of individuals."” (quoting INS v. Delgado, 466 U.S. 210,215 (1983) (quoting United States v. Martinez-Fuerte, 428 U.S. 543, 554 (1975)))); Michael H. v. Gerald D., 491 U.S. 110, 123-24 (1989) (holding that substantive due process under the Fourteenth Amendment protects some parental and family rights); Fisher v. United States, 425 U.S. 391, 408-10 (1976) (referring to prior Supreme Court cases that protect private papers in some circumstances under the Fifth Amendment). But see Paul v. Davis, 424 U.S. 693, 708-09 (1976) (holding that injury to a person's honor or reputation by itself is not a "liberty" interest under the Fourteenth Amendment).

${ }^{37}$ See U.S. CONST, amend. V ("No person shall be ... subject for the same offence to be twice put in jeopardy of life or limb ...."); see also Arizona v. Washington, 434 U.S. 497, 508 (1977) (quoting United States v. Dinitz, 424 U.S. 600, 611 (1975) (quoting Downum v. United States, 372 U.S. 734, 736 (1963)), in order to show that the Double Jeopardy Clause protects individuals from the "“"harassment ... [of] successive prosecutions"" for the same crime).

${ }^{38}$ The inclusion of conditions necessary for self-respect is argued for in RAWLS, supra note 15, at 440-46. But many of these same conditions are also singled out in the U.N. Universal Declaration of Human Rights. G.A. Res. 217A, U.N. GAOR, 3d Sess., pt. 1, at 71, U.N. Doc. A/810 (1948). In particular, see the provisions concerning nationality (Article 15), marriage (Article 16), personal dignity (Article 22), education (Article 26), and participation in cultural life (Article 27). 


\section{All-Purpose Resources}

A third category deals with various abilities and other attributes of the person, as well as external goods that have a general, all-purpose usefulness. One can mention here, in particular, skills that enable an individual to function as an independent person, communicate with others (which requires a basic mastery of a language), deal with a wide range of social situations, and engage in some form of productive work. Developing these resources requires, in turn, that the individual acquire a basic education and training. Among important external goods are reliable information, income, and other exchangeable goods.

\section{Opportunities}

The promotion of projects requires not only resources but opportunities as well. Without access to opportunities, resources cannot be put to use. These opportunities include personal freedom, freedom of movement from one locale to another, and, at the very least, legal rights of access to the more advantaged positions in society. Moreover, with respect to those opportunities that can only be realized by concerted action, one needs access to various kinds of cooperative relations with other persons. Typically, this category includes freedom of participation in political activities.

\section{A CLASSIFICATION OF SOURCES OF RISK}

If the avoidance of substantial losses of various primary goods distinguished above is a matter of concern for the representative individual, we need also to identify the sources of risks that might threaten these losses. In very general terms, one can distinguish two basic sources: natural events and the actions of persons.

\section{A. Natural Events}

Natural events are one obvious source of risk. These include a wide range of adverse weather conditions, including storms, extreme heat or cold, earthquakes, droughts and floods, and fires. In addition, one can mention infestations of insects, plants, and other animals; attacks by predatory animals; and contagious and genetically based diseases. 


\section{B. The Actions of Persons}

The risk to an individual may stem from the private acts of other members of one's own society, or from the private acts of persons outside of one's own society ("foreigners"). It may also stem from the organized or authorized acts of persons who are charged with maintaining order and administrating the prevailing rules-that is, from actions of domestic or foreign public officials of one sort or another (legislative, judicial, or executive). Finally, one must also include oneself as a source of risk, since one's own actions can expose one to serious harm.

\section{THE MANAGEMENT OF RISK}

Given the various types and sources of risk, how is any particular type of risk to be managed? In order to address this explicitly normative issue, a number of crosscutting considerations need to be explored: First, there are issues still to be addressed regarding how considerations of prudence are to be factored into rational deliberation. Second, there is the question of whether it is appropriate to let the matter of dealing with risk lie with the individual, or whether, at least for certain forms of risk, cooperative action is needed. Closely connected to this is a third question: whether the degree of risk to which the person is exposed is something that can be voluntarily controlled by the individual, or whether the risk in question is one to which the individual is involuntarily exposed. Finally, with respect to the risk that can only be managed by collective action, there is the question of whether social, commercial, or public institutions offer the most appropriate means to manage the risk.

\section{A. Factoring Prudential Concerns into Deliberation}

Here we face a number of significant complications. As I argued in Part I.B, it is unclear that rational persons must take prudential considerations into account. Even if the nature of their interests makes it rational to do so, this does not settle the issue of what is a rational (or even reasonable) level of concern, that is, what constitutes a "rational" or reasonable balancing of prudential concerns against the concern to choose so as to maximize expected return. Moreover, allowances must be made for the fact that individuals differ in the relative emphasis that they place on the importance of the various primary goods or resources delineated above in Part II. If individuals can reasonably differ about how much weight should be placed on pru- 
dence, and which are the more important objects of prudential concern, how, then, are we to resolve these differences within the public arena? Let me defer these questions, however, as there are other matters that we need to consider-matters whose consideration may help to clarify these normative issues.

\section{B. Personal Control of the Level of Risk to Which One Is Exposed}

One key to understanding how prudential concerns can be dealt with appropriately is to consider the extent to which the representative individual can control the level of risk to which she is exposed. In most societies there is a significantly large area within which persons can make their own decisions regarding the amount of risk to which they are willing to be exposed. Those who want to surf, hang glide, explore caves, or climb cliffs can do so, and those who find these activities too risky can refrain. Similarly, individuals can typically select a profession that is consistent with their concerns about risk. Some people will be willing to expose themselves to the dangers associated with being a police officer, or working with hazardous materials, while others will choose safer professions. ${ }^{39}$ In the social and economic spheres, a right to refuse to join, and a corresponding right to exit, can provide a certain measure of protection. If the social or economic arrangement exposes an individual to an unacceptable level of risk, she can refuse to enter the group, or choose to exit if she is already participating. ${ }^{40}$ Similarly, the principle of prohibiting the transference of property without consent can provide persons with protection

${ }^{39}$ This does not mean that there is no need to regulate the extent and nature of risks to which individuals are exposed in such professions. When persons expose themselves to certain risks and become injured, there can be significant negative spillover effects for others, which may lead to the public regulation of the activity in question. For example, persons who are improperly trained in mountain climbing or boating can get into difficulty and have to be rescued at great expense to the public. There are also important questions that must be raised about how freely certain professions are chosen. For example, a person who grows up in a mining town and has extensive social and family relations that are important to her may have little choice but to accept employment in the mine. Similar questions can be (and have been) raised about the concept of a voluntarily based military service, since many disadvantaged young adults may have few alternatives to entering military service. See Charles C. Moskos, Making the All-Volunteer Framework: A National Service Approach, 60 FOREIGN AFF. 17, 20 (1981) (noting that the all-volunteer military recruits consist of "large numbers of youth ... who ha[ve] no real alternative job prospects").

${ }^{40}$ The implications of having the option of exit are discussed at length in ALBERT O. HIRSCHMAN, EXIT, VOICE, AND LOYALTY: RESPONSES JO DECLINE IN FIRMS, ORGANIZATIONS, AND STATES (1970). 
against an important class of risks, by allowing them to be the judge of whether or not there is too much risk involved in some proposed transaction. ${ }^{41}$

In virtually any society, however, individuals are subject to certain risks over which they have little or no control. For example, the authorized actions of public officials impose a wide range of obligations on persons that do not flow from voluntary choices on their part, and failure to meet these obligations typically carries with it negative sanctions, and, more generally, the imposition of liabilities, financial and otherwise. This is the case regardless of the method of collective choice-whether the public choice procedure involves a relatively autocratic command and control structure or more democratic processes. Even in the case of the most democratic of processes, the collective choice upon which the society settles will typically be one that some individuals do not support, precisely because it imposes costs upon them.

Beyond publicly authorized actions, the social and economic (as distinct from political) actions of other individuals or groups of individuals can impose risks on any given individual. One's control here, especially in the marketplace, is most imperfect. Any given person's livelihood and health can be adversely affected by the publicly allowable acts of others. Individuals or groups of individuals may undertake social and/or economic activities that are either intentionally or unintentionally disadvantageous to some other person. Thus, one's property value can be reduced by a decision on the part of a neighbor as to how her property will be used. ${ }^{42}$ Alternatively, the neighbor may sell her property to someone who wants to use it for commercial purposes, and this can impact negatively on other property owners in the area. $^{43}$ Sometimes the impact of the permissible actions of others is

${ }^{41}$ In contrast, the market principle allowing for transference by mutual consent can be defended on the ground that individuals expect to benefit from such consensual exchanges.

${ }^{42}$ By the same token, one person's actions may directly or indirectly benefit another, and similarly, the coordinated actions of a group of persons may benefit individuals not in the group.

${ }^{43}$ Individuals may seek protection against such a change in usage by adopting zoning regulations. The immediate effect of the zoning restriction may be to lower the price of one's property, but one may be willing to incur this loss in order to protect oneself against other commercial buyers moving into the neighborhood. Buchanan and Tullock cite a somewhat different zoning requirement as an example of a desirable protection, namely, the requirement that a variance in an existing zoning ordinance receive near-unanimous consent of those whose property will be impacted upon. BUCHANAN \& TULLOCK, supra note 13 , at 74. 
much more indirect. Thus, for example, technological developments may place persons in a position where they have to expose themselves to certain risks whether they want such exposure or not, such as when persons have to use various forms of public or commercial transportation in order to pursue a livelihood.

In what is to follow, I shall assume that the appropriate focus of our attention should be on what constitutes a rational way to manage risks over which one cannot exercise personal control or where the exercise of such control would be very costly to the individual (e.g., by refusing to expose oneself to the risks involved in travel by commercial airlines or trains). To the extent that risks can be controlled by the voluntary choices that persons make as individuals, and where the exercise of such control does not require a significant sacrifice of other values, it is plausible to suppose that risk management is appropriately left up to the individual.

\section{Risks that Require Collective Management}

While some risks can be reduced by private choices, there are many risks that require, for their management, cooperative action by a number of people. A system of internal order, which provides each with security with regard to person and property, requires private and/or public organizations that are committed to maintaining such an internal order. Typically this means assigning certain persons specialized roles in which they are charged with monitoring the actions of others, and with apprehending, punishing, and exacting compensation from those who violate the rights of others. Similarly, protection against foreign threats requires the creation of elaborate and expensive armed forces. Dealing with threats from nature also typically requires coordination of action. Certain kinds of natural catastrophes can only be prevented or reduced in their severity by large-scale, concerted actions (such as the building of dikes and dams). In addition, prudence calls, at the very least, for various kinds of disaster relief programs, so that citizens may be provided with help in the case of unavoidable natural disasters. The risks of infection and disease similarly require health organizations that can both control the spread of diseases and provide persons with treatment for their individual health problems, whether those have arisen from the acts of others or of nature. Finally, bodily integrity can only be sustained if one has access to certain basic necessities-food and water, clothing, shelter, exercise and rest, and effective and safe ways to dispose of bodily 
wastes-which individuals may be unable to supply for themselves, due to the actions of others or nature.

\section{Alternative Methods for the Collective Provision of Protection}

Consider now the class of risks whose management requires concerted cooperative action. What approaches can be taken to the collective management of such risks? If one distinguishes between governmental arrangements that involve constitutional provisions and those that are authorized by persons occupying legislative and executive roles, then one can mark, in summary, four general ways of collectively managing risk: socially, commercially, legislatively, and constitutionally.

Many forms of protection have traditionally been provided by social, as distinct from commercial and governmental, arrangements. Historically, private, consensual, customary, and philanthropic arrangements between private individuals have accounted for an enormous amount of what we think of as basic protection for persons against the vicissitudes of the marketplace, of political processes, and of natural forces.

There is, in addition, a whole range of concerns that can be, and have historically been, dealt with by commercial arrangements, by having concerned individuals pay commercial firms to provide protection against various forms of risk. Thus, for example, individuals can purchase insurance against certain kinds of eventualities, including not only natural forces, but also the actions of others. But individuals may choose to resort to commercial services that prevent, rather than simply compensate for, various kinds of losses. Thus, for example, individuals who live in a certain area may choose to hire additional security guards who will be able to offer a higher level of protection against crimes, such as theft, than the protection that may be provided publicly.

Governments have traditionally managed some risks. The most obvious example is protection against foreign aggression and domination. But government action is also taken to be central to protecting against, and providing compensation for, the illegal actions of one's fellow citizens. ${ }^{44}$ And it is also employed in the case of certain projects

${ }^{44}$ Thus even some committed libertarians are prepared to accept that stateorganized protection against the illegal acts of other private individuals is appropriate. See RoberT NOZICK, ANARCHY, STATE, AND UTOPIA $113-18$ (1974) (concluding that the protective association dominant in a territory is a state). Nozick supposes that these 
that are designed to offer protection against the destructive forces of nature.

The public provision of protection itself can take one of two forms. First, public projects can be initiated by legislative enactments, the passage of which is determined by (some variant of) a majoritarian rule, and the enforcement of which is typically entrusted to executive officers. Second, protection may come in the form of "constitutional" provisions, which establish entitlements for citizens to certain basic protections or services. These are sometimes, as in the case of the U.S. Constitution, set forward in a "bill of rights," which is an explicit part of the constitutional structure (and subject to revision only by a heightened majority). Alternatively, they may be incorporated into legal precedent. In either case, the interpretation of such rights is typically entrusted to a judicial, as distinct from a legislative, process.

\section{THE NORMATIVE ISSUES}

The central questions, to which I now want to return, are normative. First, there is the question whether there are rational grounds on which protections can be cooperatively sought; and second, granting that at least some forms of essentially involuntary risk require concerted cooperative activity for their rational management, what can be said about the relative (that is, comparative) advantages of the different ways of managing the risks that were distinguished above?

With respect to the first question, the argument presented in the proceeding Sections is that the appropriate model for understanding the rational management of risks is through the kind of prudential pooling of risks and resources that takes place in insurance and mutual help schemes. ${ }^{45}$ This is not to deny that there may be other perspectives that provide reasons for the collective management of riskperspectives that speak to considerations of moral, political, or relig-

services are originally privately contracted for, but argues that standard economic considerations favor their centralization and professionalization, so that, on his account, there is a defensible move from private protection organizations to a publicly guaranteed order, i.e., to a minimal state. $I d$. at 110-13.

${ }^{45}$ This theoretical perspective closely matches the conclusions very recently put forward, on the basis of an extensive analysis of empirical data, by ROBERT E. GOODIN ET AL., THE REAL. WORLDS OF WELFARE CAPITALISM (1999). Their work is based on panel data from Germany, The Netherlands, and the United States. On the basis of that data they argue that the much more extensive government welfare program in The Netherlands is best understood as an effective way to provide needed insurance for persons. Id, at 252 . 
ious duty. But prudence offers a powerful argument for collectively managing a wide variety of risks, even if persons differ as to the level and kind of protection they are concerned to put in place. Let me now turn, then, to consider what can be said, from a general and comparative point of view, regarding the alternative ways that were distinguished above for the collective management of prudential concerns.

\section{A. The Argument for the Minimal State View}

Libertarians have sought to defend an extreme thesis regarding the provision of protections, according to which the state should be responsible for only certain very specific, and limited kinds of protection (against external threats, internal disorder, and violations of property rights) and not others. ${ }^{46}$ This amounts to an acceptance of governmental arrangements, but only for a very limited set of concerns.

One familiar line of reasoning in defense of this position is that individuals have certain "natural rights" concerning their person and their property, rights that exist prior to any form of government and which governments must respect. ${ }^{47}$ On the typical account, anything but the most minimal of governments would lead to violations of these rights. ${ }^{48}$ There are, however, two serious objections that can be raised to this selective appeal to such rights: First, the epistemological basis for the rights-claims in question is extremely weak. Essentially, proponents of the limited government thesis appeal to what they take to be self-evident first principles regarding the moral rights that persons have. ${ }^{49}$ But the appeal to self-evidency here is merely an appeal to what the proponent takes to be "intuitively" obvious. "And such "in-

46 See NozICK, supra note 44, at 10 ("Individuals in ... [a] state of nature are in 'a perfect state of freedom to order their actions and dispose of their possessions . . a as they see fit." (quoting LockE, supra note 2, at ch. ii, para. iv)).

${ }^{47}$ See id. at ix ("Individuals have rights and there are things no person or group may do to them (without violating their rights).").

${ }^{48}$ Id.

${ }^{49}$ See $i d$. at $28-29$ (presuming that individual moral rights exist before a societal structure is created).

${ }^{50}$ The typical starting point for the libertarian is an appeal to the doctrine of natural law as found, for example, in Thomist philosophy. See, e.g., MurRAY N. ROTHBARD, THE E'THICS OF LIBERTY 3-24 (1982) (describing "Thomist Tradition"). But this involves an appeal, once again, to the very Cartesian approach that Locke and Hare have so convincingly critiqued. See supra note 12 and accompanying text (criticizing the Cartesian approach to deducing self-evident truths). Sometimes the appeal to 
tuitions" tend to vary distressingly from one group to another. Those who appeal to the self-evidency (intuitive certitude) of certain socalled personal and property rights characteristically find themselves speaking to the circle of those already convinced, with little, if anything, to offer those who view things differently. Second, we are offered no argument as to why these particular rights are held sacred and not others. Why should we suppose, as advocates of the minimal thesis insist, that there should be a public guarantee with respect to a right to the fruits of one's labor, or to whatever property one manages to acquire, but not to, say, the having of property itself, or to public help in time of need?

A second, and quite distinct, line of argument for the minimal state thesis might seem more promising, since it proceeds specifically from considerations of prudence. The argument is that the kind of centralized power that is entailed by the public provision of welfare benefits, insurance, and the like, poses a deep risk to individuals." Such centralization of power exposes persons to the real risk of government domination. ${ }^{52}$ There is no question but that this argument has exerted an enormous influence on modern debates over the proper scope of government. ${ }^{53}$

Once again, however, there are substantial objections that can be raised against this line of argument. In the first place, little recogni-

the doctrine of natural law or rights is made without even a pretense of a defense of the principles to which appeal is made. Nozick, for example, appeals to Locke's theory of natural rights, which provides him, he tells us, with a "moral background" from which to proceed to make the case for no more than a limited state. See NozICK, supra note 44, at 3-9 (asserting that "Locke's state of nature... [is a] completely accurate statement of the moral background"). Nozick is careful to note that the "completely accurate statement of the moral background, including the precise statement of the moral theory and its underlying basis, would require a full-scale presentation and is a task for another time." Id. at 9 . Alas, Nozick did not manage to complete this task. But he informs us that he takes (minor) comfort in the consideration that he is simply following in this regard "the respectable tradition of Locke, who does not provide anything remotely resembling a satisfactory explanation of the status and basis of the law of nature in his Second Treatise." Id. Thus, the whole of Nozick's case for the minimal state rests on a premise for which no evidence is offered.

${ }^{51}$ The classic statement of this view is contained in FRIEDRICH A. HAYEK, THE RoAd to Serfdom (1944). But see Friedrich A. Hayek, The Constitution of LIBERTY 133-47 (1960) (presenting a much more nuanced and careful statement of his thesis).

${ }^{52}$ The focus on protection against domination, rather than protection against interference, is the theme of Philip Pettit's recent work, REPUBLICANISM: A THEORY OF FREEDOM AND GOVERNMENT (1997).

${ }^{53}$ For an illuminating discussion of this, see GARY WILLS, A NECESSARY EVIL 297 308 (1999). 
tion is given to the consideration that this is just one of many risks that are typically the object of prudential concern. With the exception of committed anarchists, no one argues that the risk of placing power in the hands of the government councils against government protection from foreign invasion and private disregard of the rights of others. But what, then, is the argument that these forms of governmental protection are acceptable while others are not? Second, there are alternative ways in which the problem of the concentration of power can be addressed-specifically by the introduction of constitutional constraints, a system of checks and balances, and the decentralization of governmental control.

The third, and perhaps most persuasive, line of argument is that governmental programs in these various areas prove to be no more than a second-best way to provide individuals with protection-and that social and/or commercial arrangements can accomplish the same thing in an economically more efficient manner. This argument invokes, in effect, considerations of mutually expected gain rather than prudence.

The history of arguments from considerations of mutually expected gain is, however, quite complicated. In the twentieth century, in particular, mutual gain has repeatedly been invoked in support of expanding government programs. ${ }^{54}$ The argument is that many of the goods that persons desire constitute public goods in the technical sense of that term. That is, the provision of such a good to one citizen does not necessarily diminish the amount that can be provided to another, and, at least under present and foreseeable technological conditions, when its benefits are provided to some, one cannot exclude other members of the society from benefiting as well. These, then, are goods whose supply cannot be targeted to only those persons who are willing to pay for them. In standard economic analysis, this means that if it were left to commercial organizations to supply such goods, they would inevitably be undersupplied. Economists have typically used this kind of "market failure" argument to defend the public (as distinct from the commercial) provision of certain goods. ${ }^{5.5}$ National

\footnotetext{
${ }^{54}$ See, e.g., James M. Buchanan, ThE BaSES for Collective ACTion (General Learning Press 1971).

${ }_{55}$ For the details of this sort of argument, see Kenneth J. Arrow, The Organization of Economic Activity: Issues Pertinent to the Choice of Market Versus Nonmarket Allocation, in JoINT ECON. COMm., 91st Cong., THE ANalysis and Evaluation of Public EXPENDITURES: THE PPB SYSTEM 47-64 (Comm. Print 1969).
} 
defense, education, and many other goods are thought to have this character. $^{56}$

In more recent years, however, defenders of the minimal state view have used a variant of this argument to resist the expansion of public programs. They have argued that if market processes tend to be less than fully efficient (by virtue of "market failure" problems), public forms of provision are also inefficient in their own way. The issue is thus which of two imperfect processes is, in the balance, the least imperfect, and the conclusion is that economic and social, as opposed to government, programs are better in this respect. ${ }^{57}$

One basic problem with this sort of argument is that even if a given way of providing security is associated with lower costs (and thus a higher expected return) than some other approach, this does not yet speak in favor of that approach. The more costly approach may, after all, offer more security to the representative person and this, for one who is prudent, may be a decisive consideration. ${ }^{58}$

Whatever support the limited state view can find within the framework of a theory of prudential choice will have to come from a much more careful sorting out of the comparative advantages of the various ways of managing risk: social, commercial, and governmental. Let me now turn, then, to what can be said in that regard.

\section{B. The Social Provision of Protection}

With respect to a wide range of the concerns delineated above, the historical solution has been for security to be socially supplied. In most traditional societies, virtually all of these concerns, insofar as they are met at all, are met locally by social rather than political institutions. What characterizes such societies, however, is that membership in the basic social groups is relatively stable. That is, in traditional societies persons are born into a certain social group, and most

${ }^{56}$ For example, if a group of persons in a neighborhood hire a private security force to combat theft in the area, all who live in that area benefit, whether or not they contribute to the costs of maintaining such a security force.

${ }^{57}$ A carefully argued version of this line of reasoning is to be found in RICHARD A. EPSTEIN, PRINCIPLES FOR A FREE SOCIETY 71-75 (1998). Epstein embraces the principle of res perit domino ("losses lie where they fall"), and argues against public risk sharing and programs, and in favor of some combination of social and commercial forms of protection. See id. at 74-75 (describing the wisdom of res perit domino in the context of insurance).

${ }_{58}$ See supra Part I.A (discussing why purchasing insurance means accepting a lower expected return). 
of them remain within that group. This means, of course, that insofar as there are resources available to the social unit, persons in such societies have considerable assurance that their prudential concerns will be met.

Within the context of modern, market-oriented, adaptive, and open societies, however, things are very different. Such a society provides the opportunity for greatly increased material well-being. Growth, however, requires that markets become increasingly open, and this, in turn, requires mobility of individuals. ${ }^{59}$ Persons must be prepared to move out of the local (village) setting if they are to capture the opportunities available in an open society. On the other hand, the deeply personalized relationships that provide the network of social support in the village do not so easily transport, and thus are usually left behind. ${ }^{60}$

The kind of mobility required for expanding markets, then, is inconsistent with the social supply of security. The expansion and rationalization of the market process itself generates the need for alternative ways of meeting prudential concerns. That is, the economic rationalization of relations between persons creates the very conditions under which traditional forms of social security-based on kinship, clan, and village organization of social relations-can no longer provide the needed protection."

\section{The Market Provision of Protection}

I have already acknowledged that individuals can differ significantly with respect to how much risk they are willing to bear. Given such variability, the idea of supplying certain forms of security through the marketplace itself via the purchase of insurance or specialized protection services is extremely attractive. Insurance is typically available in the marketplace to compensate for health problems, bodily injury, and loss of property. Similarly, one can purchase services that include bodily and property protection, information, and

59 See Avner Grief, Cultural Beliefs and the Organization of Sociely: A Historical and Theoretical Reflection on Collectivist and Individualist Societies, 102 J. POL. ECON. 912, 94244 (1994) (concluding from a historical case study that a social system of individual mobility is more efficient, leading to greater economic growth).

60 The logic of a market society in this regard is expounded in ERNEST GELLNER, CONDITIONS OF LIBERTY 97-102 (1994).

${ }^{61}$ See Partha Dasgupta, AN InQuiry into Well-Being and Destitution 104 (1993) (arguing that a state committed to economic growth cannot avoid responsibility for a civil society to substitute for "tribal, or clan, or religious, or ethnic loyalties"). 
even access to social contacts. Such methods allow persons, in principle, to realize their preferred level of risk bearing.

The standard objection to the commercial supply of many forms of protection has been, as already indicated, that these goods are public goods that theoretically will be undersupplied by the market. In the last three decades, this thesis has been subject to a sustained critique. $^{62}$ One obvious response is that the "market failure" or undersupply problem is essentially a problem with exclusion, i.e., sellers are unable to effectively exclude nonpurchasers from enjoying benefits. However, many problems of this sort are really only technical problems that can (and will) be resolved by innovative measures. Moreover, as I noted above, ${ }^{63}$ arguments about the market failures can be countered by arguments regarding government failures.

There is, however, a distinct and much more telling objection to commercial forms of protection, which is that there is nothing in the nature of market processes themselves that assures that persons will be able to purchase the insurance or services they need and desire. It is money that provides one with access to commercial protection. Thus, there will be no assurance that all will receive either the needed or desired protection. And this is something about which the prudent person must be concerned. The problem is greatly exacerbated by the way in which markets work, since private suppliers of insurance are naturally disposed to seek out those who are less risky, or to charge more risky persons with a higher premium. Either method leads to less protection for the less fortunate.

\section{The Governmental Supply of Protection}

Provisioning in the United States takes the form of public programs such as unemployment insurance, Medicare, AFDC, and welfare support that are generated by whatever political processes are in effect. In principle, this is supposed to resolve any "market failure" problems and also fix the problem of uneven coverage associated with the commercial supply of protection.

Regardless of whether a society's political structure is radically democratic or highly autocratic, however, it is still the case that the individual beneficiary has little control over the decision-making pro-

${ }^{62}$ For the most important contributions to this critique, see the collection of articles in THE THEORY OF MARKET FAILURE: A CRITICAL EXAMINATION (Tyler Cowen ed., 1988).

${ }^{63}$ Supra Part V.A. 
cess for determining what protections will be publicly provided, and at what level. This is obvious in the case of autocratic political rule, but is no less true in a democracy. There is no assurance that one will not end up being a member of a minority, whose concerns are continually overridden by a stable majority. Once again, the representative individual lacks any real assurance that protection will be available if supplied by political processes. And this will be a matter of prudential concern. That a given society has in fact an extensive welfare program in place does not resolve the prudential concerns of its members. The question, once again, is what assurances do persons have in that society that such benefits will continue to be provided.

The provided level of support is an especially critical problem. There is no guarantee that the levels of protection provided by ordinary political processes will meet the concerns of many in such a society. That is, there is no assurance that ordinary political processes, democratic or autocratic, will provide a higher, rather than a lower, level of protection. It all depends upon the choices made by thoseindividuals or groups-who hold power in a society.

There is another objection to settling upon lower levels of protection. In any modern society in which there is a significant range of commercial protection available, when a lower level of protection is provided by public means, those who are financially capable will still have the option of supplementing public protection with private arrangements. Under those conditions, basic protections become even more unevenly distributed.

In summary, there are substantial objections that can be raised to letting the supply of protection be decided by ordinary political processes. ${ }^{64}$ From a prudential point of view, the whole point of a system of constraints is to mark out areas in which the representative participant will have assurances that certain issues are not settled by ordinary processes of give-and-take, based on bargaining advantages and power.

\section{E. The Constitutional Supply of Protection}

The constitutional approach to protections offers a way to overcome the shortcomings of a legislative/administrative management of

${ }^{64}$ Once again, the thrust of Buchanan and Tullock's argument is that it would be imprudent for persons to leave this as a matter to be settled "democratically." BUCHANAN \& TULLOCK, supra note 13 , at 7484. Their argument is that it is rational to set limits on what can be decided by majoritarian voting procedures. Id. at 72. 
prudential concerns-by providing persons with an assurance that the issues of protection will be relatively immune from decision-making processes that are discretionary with regard to both the kinds and the level of protection offered, and also the class of participants to whom it will be offered. Such an approach is characteristic of collective decision making at virtually every level of civil society, including clubs, associations, and fraternal organizations, in which cooperative arrangements are employed, and where ordinary issues regarding the way in which coordination is to be structured are settled in an administrative or democratic fashion. ${ }^{65}$

The appropriateness of a prudential hedge becomes clear, moreover, when the issue is not how to structure voluntary associations which persons can enter and exit without significant penalties, but, rather, where persons are understood to be bound by restrictions not arising from specific consensual acts (such as joining an organization or entering into a contract). These restrictions occur when persons define their basic civil relations to one another. ${ }^{66}$ This is the sort of situation, for example, to which the United Nations Declaration of Human Rights ${ }^{67}$ is intended to apply.

Such a constitutional approach is designed to provide people with a range of public programs and corresponding legal remedies that lie out of reach of the political agenda of the day. Moreover, and most importantly, this approach can be designed to apply to all members of the society, i.e., to provide universal coverage. Whatever the costsaving merits of arranging for the bulk of decisions to be made by democratic and/or administrative processes, it is still the case that where substantial issues are at stake-where the costs of an adverse decision could turn out to be prohibitively high-participants will find it prudent to insist on something more approximating a rule of una-

${ }^{65}$ In particular, this principle is central to the widely utilized Robert's Rules of Order. HENRY M. ROBERT, RoberT's Rules OF ORDER (Sarah Corbin Robert et al. eds., 10th ed. 2000) (1876).

${ }^{66}$ As $I$ indicated in the Introduction, a model for this way of addressing prudential concerns is to be found in BUCHANAN \& TULLOCK, supra note 13. While they are prepared to defend less-than-unanimity rules for collective choice on the ground of the savings to be achieved thereby in terms of decision-making and opportunity costs, they clearly anticipate and incorporate a substantial prudential concern. $I d$. at 72 . That is, it is central to their argument that it is rational for individuals to agree, in addition, to a constitution-to the specification of heightened majority rules to apply to certain classes of policy matters. See id. (noting that an individual will accept "the additional burden of [supermajority] decision-making in exchange for additional protection against adverse decisions").

${ }^{67}$ G.A. Res. 217A, supra note 38. 
nimity. ${ }^{68}$ The root idea is not to remove every element of risk from the choices that participants make, but to provide a basic set of protections, available without discrimination to all members of society, that will allow individuals to then move on and adjust their own activities to whatever their own personal preferences are with respect to risks. In particular, and most importantly, such protections can provide a consensual basis for the acceptance of the residual kinds of risks that are inherent in a market-oriented economy.

A constitutional arrangement, of course, does not offer an unconditional guarantee. It remains the case that the constitution itself can be amended (in accordance with some super-majority rule), which means that individuals can still be deprived of virtually any type of protection. But the constitutional approach significantly increases the likelihood that an individual will be assured a significant range of protections. Given the usual articulation of distinct and separate legislative, executive, and judicial branches of the government, the constitutional approach to protection also has the attractive property that the power to interpret protective standards will not be vested in officials whose elective status makes them subject to political interest groups. Under a constitutional system, such interpretive power will typically be vested in the judicial arm of the government, where there is arguably a better chance of insulating the interpretive process from such influences.

\section{F. The Question of the Scope and Level of Protection}

I have argued for a constitutional approach to the management of a wide spectrum of risks. The argument is very general, turning as it does on the idea that prudence requires a kind of assurance that sim-

\footnotetext{
${ }^{68}$ It should be noted that Buchanan and Tullock explicitly refer to a constitution that establishes certain basic rights, and they discuss a special, prudentially oriented calculus that is appropriately applied to actions that "modify or restrict the structure of individual human or property rights after these have once been defined and generally accepted by the community." BUCHANAN \& TUllock, supra note 13, at 73. Speaking to this point, they also argue that

[c]onstitutional prohibitions against many forms of collective intervention in the market economy have been abolished within the last three decades. As a result, legislative action may now produce severe capital losses or lucrative capital gains to separate individuals and groups. For the rational individual, unable to predict his future position, the imposition of some additional and renewed restraints on the exercise of such legislative power may be desirable.

$I d$. at 82 . This suggests that they would probably not be prepared to extend this line of reasoning anywhere near as far as I shall propose in the next Section.
} 
ply cannot be supplied, at least in modern market-oriented societies, by social, commercial, and nonconstitutional forms of public governance. But the very generality of this line of reasoning has important implications for the scope of the argument-for what kinds of protections should be secured by constitutional means. There are a number of issues related to scope and level of protection, in particular, for which the argument regarding prudence has important implications.

The first issue of scope concerns whether constitutional restrictions on government action should be confined to the actions of the central government or whether, given a more complex form of governance, including the assignment of various matters to more local governance units such as state, city, or township, constitutional restrictions should be imposed on these local units as well. Of the various kinds of losses against which persons would want some sort of protection, it might seem that those stemming from the actions of the government most plausibly require a constitutional restriction on the government itself. Concerns about social security, health care, largescale programs that deal with the destructive forces of nature, and the protection of property, life, and limb, could all, in principle at least, be supplied by nongovernmental agencies-that is, by social and/or commercial institutions. In contrast, misuse of government power or action would seem to be something that could only be handled by a refinement of government power itself through a restriction on, rather than an expansion of, governmental activity. ${ }^{69}$ It is this sort of problem for which constitutional restrictions on governmental activity —in the form of, say, a "bill of rights"-especially makes sense.

If the rationale for such constitutional restrictions were set out simply in terms of the need to protect against the centralization of power, it might be possible to make the case that it is only the actions of the central government that need to be restricted. However, on the account I have offered above, the problems that can and should be addressed by constitutional devices are not just the risks that arise as the result of the actions of central authorities, but the wide range of risks posed by actions of other individuals, in either their public or private capacity, and those due to acts of nature. That is, the argument has been that it is rational for individuals to seek protection against the arbitrary acts of regional and local officials and delibera-

\footnotetext{
${ }^{69}$ To be sure, some have argued that a stable democratic order involves more than just restrictions on government-that it requires the presence of a dense network of civil and social associations. See Robert D. PUtnam et AL., Making Democracy WORK 167 (1993) (describing the positive effects of social organizations on collective action).
} 
tive bodies, the acts of individuals in their private capacity, and acts of nature, no less than against the arbitrary acts of agents of the central government. $^{70}$

A second and more controversial issue of scope concerns the extension of the constitutional approach to the protections that have traditionally been associated with a safety net or welfare floor, including access to adequate food, water, clothing, shelter, and facilities for disposing of bodily wastes; opportunities for exercise and rest; a minimum level of income or other exchangeable goods; meaningful work; and adequate legal representation and health care. But here, no less than in the case of the extension of protection against arbitrary procedures from central to more local forms of government, it is unclear what basis there could be, from a prudential perspective, for the traditional emphasis in the American experience simply on the protections afforded by the Bill of Rights. It is clearly prudent to insist on freedom of association, religion, and the press, as well as protection from arbitrary searches and seizures. But it is equally prudent to insist on basic safety nets, educational rights, and rights to legal and medical assistance. The issue here is neatly captured in the striking difference between the U.S. Bill of Rights and the U.N. Universal Declaration of Human Rights." The former is overwhelmingly preoccupied with procedural, association, and opportunity rights, while the latter, though including all of these, extends to include a variety of "positive" rights of a kind associated with the concept of a basic social minimum.

The difference between the two approaches is profound. The first, on its original construction, offered persons the assurance that they would have protection against the actions of officials of the new central government. Later, these protections were extended to the actions of state and local governments. But on either construction, the Bill of Rights's provisions are limited to providing protection against certain coercive acts of public officials. The U.N. Declaration offers all of the protections of the Bill of Rights, but extends the concept of human rights to cover a very wide range of additional concerns. In particular, and in sharp contrast to the Bill of Rights's provisions, it offers the individual assurance against being placed in a

${ }^{70}$ There is, to be sure, an important difference between the controls exercised by the most general political unit to which the individual belongs, and those exercised by all other, more localized units. If freedom of movement is assured, one natural check on local repression will come in the form of the persons who are subjected to such repression voting with their feet, that is, by exiting the local unit in question.

${ }^{71}$ G.A. Res. 217A, supra note 38. 
position in which, because of the vicissitudes of natural events and the unintentional actions of other persons, the individual has to choose between the lesser of two great evils. ${ }^{72}$ The reality of social and commercial interactions is that they can work out in a manner that deeply compromises the interests of some participants (without anyone intending this). A system based on no more than the kinds of guarantees embodied in the U.S. Constitution offers persons very limited protection. Specifically, there is no assurance that actions of others and/or natural events will not severely erode one's own position and one's own ability to provide the basic necessities for oneself and one's loved ones. In contrast, the incorporation of certain basic welfare rights means that citizens are provided with a secure initial position from which they are free to voluntarily enter into a wide range of social and commercial alliances-but only on terms that do not involve forced choices, in which certain needs will have to be sacrificed in order to meet others.

With regard to the issue of the level of protection it is appropriate to secure, the following considerations can be offered in support of a higher rather than a lower level of protection. First, when the level of security is set lower rather than higher, some will simply have to live with less security than they either need or desire. Only some will be faced with this problem, of course, because others-those who are better off financially, and who are also risk averse-can supplement public protections with commercially provided protections. But, as already noted, that simply increases the unevenness of the protections that each is able to secure. By way of contrast, if the concerns of the more risk adverse are publicly met, some, to be sure, will find themselves with more protection than they desire. But the two situations are not symmetrical. Those who are provided with greater security than they desire will typically not have a complaint regarding the level of protection provided, although they may, of course, complain about the cost of the unwanted protection. This is because there are ways in which the more risk oriented can still indulge their interest in living in a more risky manner. The more risk oriented can simply choose not to exercise their "right" to a higher level of protection (e.g., they can

${ }^{72}$ Hobbes argues in Leviathan: "Fear and liberty are consistent, as when a man throweth his goods into the sea for fear the ship should sink, he doth it nevertheless very willingly, and may refuse to do it if he will." HoBBEs, supra note 1, at ch. xxi, para. 3. But this does not in the least undercut the point that it is not prudent to put oneself in a situation in which one's only options are to lose one's goods or one's ship (or perhaps, more accurately, one's life) - that is, to have to choose between such important primary goods. In ordinary parlance, we would speak of this as a forced choice. 
refuse social security or unemployment benefits). Alternatively, and in response to the issue of financial burden, those who desire less security can be offered monetary compensation in return for giving up their right to protection. In effect, they can be offered venture capital shares in exchange for security shares.

Second, there is empirical evidence, in the form of revealed preferences, that the general level of affluence achieved in any given society is relevant to what individuals are prepared to demand in the way of protection. The increasing affluence that well-organized economic activity produces has been associated historically with increasing concern for security. Moreover, there is evidence that persons tend to demand a higher level of security or protection in situations where they have no (or little) control over the risks to which they are exposed-i.e., when there is little they can personally do to control the risks. ${ }^{79}$ This suggests that in a modern, economically advanced society, characterized by extensive and complex forms of cooperation that generate risks over which individuals have little power of control, one can expect that higher levels of protection will be acceptable to participants.

Third, it must be acknowledged that responding to the prudential concerns of participants involves the expenditure of scarce resources. Real protections are not costless. ${ }^{74}$ The question of an appropriate level of protections cannot be settled except within the context of a comprehensive theory of public policy based on a clear understanding of the kinds of trade-offs that are involved, and how scarce resources are to be allocated. There is one cost in particular that must be carefully factored into the analysis. There are whole ranges of activities where the provision of protection raises the problem of what economists term "moral hazard." The problem is that a high level of protection can leave persons insufficiently motivated to take due care, so that the probability of certain adverse events can increase as a result of providing such protection. ${ }^{75}$ For instance, if one could fully ensure

${ }^{73}$ See Chauncey Starr, Social Benefit Versus Technological Risk: What Is Our Society Willing to Pay for Safety?, 165 SCIENCE (n.s.) 1232, 1233-34, 1237 (1969) (defining "involuntary" activities as activities that are out of one's control and concluding that quantitative methodology suggests that people are "willing to accept 'voluntary' risks roughly 1000 times greater than 'involuntary' risks").

${ }^{74}$ For a discussion of this theme, see STEPHEN HOLMES \& CASS R. SUNSTEIN, THE COST OF RIGHTS (1999).

${ }^{75}$ See, e.g., Kenneth J. Arrow, Uncertainty and the Welfare Economics of Medical Care, 53 AM. ECON. REv. 941, 961 (1963) ("One of the limits which has been much stressed in insurance literature is the effect of insurance on incentives."). 
one's goods without any deductible, one would have less reason to take care that the goods are not stolen. Having said that, it must be observed that abstract theory proves a very poor second to solid empirical data when it comes to trying to determine just how serious the problem of moral hazard is in connection with a wide variety of protective programs.

\section{IMPLICATIONS FOR A THEORY OF RIGHTS}

So far, I have simply sought to explore what sort of a case can be made for this or that alternative method for meeting certain prudential concerns. The preceding discussion points, however, to a distinct way in which one could think about what is a most important topic, namely, the place of certain principles of rights in a theory of rational political and social institutions. In the philosophical literature, there are two distinct issues that have preoccupied theorists: The first is what grounds there are for according persons various rights. The second is whether and to what extent rights claims "trump" other kinds of policy considerations.

With respect to the first of these issues, one familiar way of grounding certain rights claims is by appealing to the idea of people engaging in a joint enterprise, in which there is mutual submission to restrictions on the liberties of those involved, for the sake of mutual advantages. The assumption is that persons are willing to submit to certain restrictions in return for the benefits that flow from the arrangement, and that, typically, the benefits to any one participant are significantly conditioned by others restricting their actions. In this kind of a setting, it is customary to think that those who benefit from others submitting to such restrictions have a duty to do their part as well, and that those who have submitted have a right to submission by those who have so benefited. One can call this the principle of mutuality of restrictions. ${ }^{77}$ On such a view, rights arise within the context of

${ }^{76}$ One very recent relevant study is GOODIN ET AL., supra note 45 , which offers substantial empirical evidence against the commonplace model-theoretic claims regarding the disincentive effects of extensive welfare programs.

${ }_{77}$ H.L.A. Hart characterizes such a regulative principle in the following way: "[W] hen a number of persons conduct any joint enterprise according to rules and thus restrict their liberty, those who have submitted to these restrictions when required have a right to a similar submission from those who have benefited by their submission." H.L.A. Hart, Are There Any Natural Rights, 64 PHIL. REV. 175, 185 (1955). Hart resists classifying together the rights that arise from promises and consent ("authorization") and the rights that arise from mutual restrictions, but he is prepared to acknowledge that all of these "arise from previous voluntary actions." Id. Rawls slightly 
cooperative arrangements among persons. For the moment, we need not settle the question of whether such arrangements are best understood on the model of voluntary, consensual acts (the contractual account) or emerge somewhat more indirectly, as a matter of evolving customs or traditions (the convention account). It will prove useful, however, to explore some of the features of such an account.

First, one defines a reference point by imagining a situation in which there are no restrictions on the actions of individuals. This would be a state of maximum freedom or liberty. Viewed from that standpoint, every arrangement entered in to with others constitutes an exchange of freedom for benefits. Of course, in many cases, the exchange involves giving up certain freedoms in order to secure freedom from interference by others. But it may also be an exchange of freedom for other kinds of benefits-such as a safety net with regard to basic needs, or increased income. ${ }^{78}$ There is, in this way of thinking, no assumption that any person has a natural right to noninterference from others, or even a natural right to nondomination. ${ }^{79}$ On this account, the natural order is a "free-for-all" in which anything is permissible.

rephrases the principle and refers to it as the principle of fairness. See RAWLS, supra note 15, at 111-12 ("This principle [of fairness] holds a person is required to do his part ... when two conditions are met: first, the institution is just (or fair) ... and second, one has voluntarily accepted the benefits of the arrangement or taken advantage of the opportunities it offers to further one's interests.").

${ }_{78}$ It should be noted that Hart argues, to the contrary, that

it is ... a very important feature of a moral right that the possessor of it is conceived as having a moral justification for limiting the freedom of another and that he has this justification not because the action he is entitled to require of another has some moral quality but simply because in the circum. stances a certain distribution of human freedom will be maintained if he by his choice is allowed to determine how that other shall act.

Hart, supra note 77, at 178 (emphasis added). One can bring this formulation in line with the account I have been developing, however, by dropping the reference to "moral," and making clear that it is not just the distribution of freedom, but, more generally, distribution of benefits that is relevant here. Modified in this fashion, the claim would now be that it is a very important feature of a right that the possessor of it is conceived as having a justification for limiting the freedom of another and that she has this justification not because the action she is entitled to require of another has some quality but simply because, in the circumstances, a fair distribution of benefits will be maintained if she, by her choice, is allowed to determine how that other shall act.

${ }^{79}$ This way of thinking is to be distinguished, of course, from that found in Hart, who postulates a natural right to certain kinds of noninterference. See id. at 175 ("[T] he equal right of all men to be free [is] a natural right."). It is also different from the view taken by Pettit, for whom there is a natural right to nondomination. PETTIT, supra note 52 , at 10 .

${ }^{80}$ This is, of course, the conceptual starting point in Leviathan-the state of a war of all against all. See HOBBES, supra note 1, at ch. xiii, para. 8 ("[D] uring the time men 
The presumption against interference, when such interference is not for the sake of securing freedom from coercion, restraint, and injurious actions of others, is not an antecedent feature of the natural order. Rather, it is established by entering into arrangements with others. And such a principle of noninterference is only one of the things that a rational person will seek to have included in arrangements with others.

\section{A. Rights and Mutual Benefits}

On the account just sketched, it makes no sense to suppose that persons would accept certain restrictions on their actions except in return for some benefit. That is, individuals are presumed to be motivated to accept responsibilities out of consideration of the benefits to be derived thereby. In this sense, it is not really mutuality of restrictions, but mutuality of benefits that characterizes the kind of arrangement that gives rise to rights and duties. ${ }^{81}$

live [in the state of nature] ... [they live] in that condition which is called war; and such a war as is of every man against every man.").

${ }^{81}$ In particular, one can imagine arrangements (typically involving a complex division of labor) under which the coordination of activities is mutual in the formal sense only. That is, while each participant is subject to restrictions, these vary significantly from one participant to another. Still the coordination scheme gives rise to rights and duties by virtue of the gains to each that can be realized thereby. What happens, on this reformulation, to Hart's notion of there being a basic natural right to be free? Hart argues that

in the absence of certain special conditions which are consistent with the right being an equal right, any adult human being capable of choice (1) has the right to forbearance on the part of all others from the use of coercion or restraint against him save to hinder coercion or restraint and (2) is at liberty to do (i.e., is under no obligation to abstain from) any action which is not one coercing or restraining or designed to injure other persons.

Hart, supra note 77 , at 175 . This principle stands in uneasy tension to what Hart later endorses in the same article and characterizes as the mutuality of restrictions principle. Id. at 177-83. That latter principle, I have already suggested, makes it appropriate to limit the freedom of one person who benefits from limits others have placed on their freedom, for the sake of mutual advantages, but who refuses to accept similar restrictions. What $\mathrm{I}$ am proposing here, essentially, is a shift of emphasis from Hart's "natural right" of all men to be free to his mutuality of restrictions principle. The latter, I want to suggest, is the more fundamental. The problem is that the former, while it is certainly endorsed by many modern liberal societies, speaks, in effect, only to one kind of social concern. Individuals enter into arrangements with one another not just to secure freedom from interference, but for other reasons as well, such as for protection against hostile nature, to better serve basic needs, and, more generally, what Hobbes refers to as "commodious living." HOBBES, supra note 1 , at ch. xiii, para. 14. In making this shift I am, of course, supposing that what Hart terms (one class of) "special" rights, which he, in fact, takes as the foundation of political rights and obligations, are 
Does it suffice for the grounding of rights and obligations, in such cases, that all gain, or is there some further requirement on the distribution of the benefits that such an arrangement makes possible? $\mathrm{Mu}$ tuality of gain can exist under what are very forced arrangements between persons that provide some with large gains while others have to make do with only the most marginal of benefits. ${ }^{82}$ The view sketched above presumes that an arrangement generating rights and duties does not distribute benefits so that some are net gainers while others are net losers. But it is also open to us to insist on more than this. Suppose that some gain much more and others much less, and that the distribution is not one that could be the object of an informed consensus between participants. It can be argued that such a distribution of benefits is not rationally acceptable, and that this is highly relevant to the question of whether any such arrangement generates rights and obligations. Roughly speaking, the idea would be that only an arrangement in which benefits are fairly distributed could give rise to rights and duties. ${ }^{89}$

\section{B. Rights and Prudence}

When coordination is to take place over time, and against the backdrop of future events whose occurrence can at best be estimated, the judgment of advantage will characteristically be a judgment of $e x$ pected advantage. But that means that there is, unavoidably, an issue of risk that arises in connection with virtually any arrangement. What generates great benefits for all under certain conditions can deeply disadvantage some under other conditions. The representative person, I have suggested, will not be willing to accept just any such possible loss, just so long as there is a net positive expected return. It is precisely here that considerations of prudence play an important role in the justification of arrangements between persons. The argument of the preceding Sections is that considerations of prudence, in respect to risks involving one's access to various primary goods, give rise

the real basis for any set of rights. See Hart, supra note 77, at 183-85 (defining "special" rights as those which "arise out of special transactions between individuals or out of some special relationship in which they stand to each other").

${ }_{82}$ Of course, not all inequalities presuppose forced relations between persons. Following Rawls, we may suppose that some inequalities can be fully accepted by persons on the ground that they work out to the mutual advantage of all. RAWLS, supra note 15 , at 87 .

${ }^{8.3}$ That rights and duties are conditioned by the fairness of the practices within which they are articulated is a theme that is common to both DAVID GAUTHIER, MORALS BY AGREEMENT 1-20 (1986), and RAWLS, supra note 15, at 93-98. 
to a distinct set of rights, particularly in situations in which one is involuntarily exposed to risk.

The risks that a prudent person will seek to reduce are of one of two kinds. Either the policy in question directly exposes the person to an unacceptable risk, or while what it exposes the person to would be, in and of itself, an acceptable risk, it establishes a precedent that the person judges to be unacceptable. That is, the policy opens the door to future decisions some of which would (or could) yield unacceptable consequences for the person in question.

To illustrate the second case, suppose public policy considerations are introduced that require for their implementation only the most marginal of violations of something to which some group of persons thinks they have a right. For example, suppose great public benefits would flow from marginally restricting the movements of a small class of persons. Even granting the importance of freedom of movement, one could imagine that those whose freedom of movement is restricted still benefit in other ways from the restriction, so that the arrangement yields some mutual benefits. Suppose, for instance, that the U.S. government, in pursuit of homeland security, were to ban all those of near-eastern origin (including U.S. citizens) from traveling closer than ten miles to any military installation or nuclear power plant. Even those banned from such travel could be said to benefit from the enhanced security.

In such a case, however, society has to contend with the precedent that this might set. The significance of "slippery slope" arguments becomes clearer when one looks at them from a prudential perspective. Prudence involves seeking to avoid or protect oneself against the occurrence of certain disastrous outcomes. A precedent serves to remind one of a possible disastrous outcome to a decision process, an outcome to which the precedent is thought to open the door or render more probable. ${ }^{84}$

${ }^{84}$ Is anything gained by thinking about these situations as involving the potential loss of primary, as distinct from important, intrinsic goods? Looking back at our original list, freedom of religion and the right to a nationality in particular speak to something that many think of as having deep, intrinsic value. We can grant that many do think of them this way, but still insist that they have great instrumental value as well. It is important to recognize, however, that what is at issue here is not just the securing for oneself of certain rights, for example, freedom to practice one's own religion and make one's own nationality identification. The principle to which persons are to commit themselves is that each individual is to have these freedoms. We may suppose, then, that for each person her own religious freedom-and her own nationality-is something of intrinsic value. But the granting of these same freedoms to others (of a different religion and a different nationality) is not necessarily intrinsically valuable for 


\section{Do Rights Trump Classical Utilitarian Considerations?}

Let me now take up the other question posed at the outset of Part VI. What I have just suggested is that rights can be grounded in certain cases in consideration of what counts as a fair distribution of mutual benefits in general, and in other cases in prudential considerations. In either case, the idea that they can trump ordinary utilitarian considerations of greater aggregate gain is implicit in the whole of the foregoing analysis.

Note, first of all, that a rational but prudent person would be disposed, prima facie, to insist that policy decisions should not just produce the greatest aggregate benefits (or utility), but should produce benefits for each participant, since only then can one be sure that one will not be disadvantaged by some policy that is adopted. That is, within the framework I have developed, that a given policy would produce the greatest aggregate utility provides no ground, in and of itself, for the rational acceptance of that policy, since acceptance depends upon expected gains to oneself, and it is possible that the policy that produces the greatest aggregate utility does so at the expense of one's own advantage (or utility).

But it is also plausible to suppose that under certain conditions one would agree to the use of a utilitarian aggregation rule. Insofar as one desires to see one's interests promoted, one may find it to one's advantage to support the operation of a rule that requires the maximization of the sum of gains (utilities). This will be the case if one judges that the operation of such a rule over time will result in net benefits to oneself. That is, the operation of the rule may impose costs upon oneself in some cases, but one still expects to realize a net gain over the long run. ${ }^{85}$

To the extent that any such defense of a utilitarian rule for policy decisions could be constructed, however, it would be subject to precisely the same qualifications expressed in the idea of constitutional

\footnotetext{
the representative person. It may be viewed as only valuable as a means to one's own end, such as being able to practice one's own religion and nationality.

${ }^{85}$ The argument sketched here is one that can be adapted from the analysis that Buchanan and Tullock offer, of conditions under which rational persons would be willing to agree to a majoritarian principle of voting. See BUCHANAN \& TUllock, supra note 13, at 63-84 (employing economic theory to help explain when a reasonable person would accept a majoritarian scheme of voting). Here, no less than in the case of the operation of majoritarian rules, one can expect that there will be significant decision-making and opportunity costs to operating under the more stringent rule that requires everyone to actually gain as a result of each decision reached.
} 
restrictions on the majoritarian voting principle. That is, for a rational person with prudential concerns, a positive net expected gain would hardly be decisive. The representative individual will still want constitutional constraints that would, at least in some situations, trump considerations of expected gain. Once again, the logic of a prudential concern is such that it cannot be set to one side merely by showing that, for the individual in question, the expected gain is sufficiently large as to outweigh the expected risk, in other words, the loss discounted by its probability. ${ }^{86}$

We may suppose, then, that given prudential concerns, it is rational for individuals to agree to a constitution, to the specification of different decision-making rules for different classes of policy matters. Rational but prudent individuals may well be willing to support the operation of a utilitarian aggregation rule, but they will also find it prudent to exempt certain classes of policy decisions from such a calculus. That is, they will regard the rule as appropriate for certain policy issues, and not for others. Roughly speaking, one could expect that some version of a utilitarian aggregation rule will be selected as the appropriate rule for middle-level decision making, in which fundamental rights are not at issue in any substantial way, and where one expects a sufficiently large number of more or less similar issues to be settled by the use of the rule. This is particularly true in cases where one's own position is likely to be more or less randomly distributed, and hence where one can at least expect, over the long run, that things will balance out to one's own net advantage. On this way of thinking, the utilitarian aggregation principle has a role to play in a comprehensive approach to public policy, but the range of situations in which it would be rational to employ the principle will be significantly limited, and the limiting considerations will be expressed in terms of a set of constitutionally established basic rights. For this rea-

${ }^{86}$ This is a point, I hasten to remind the reader, that even those persuaded by the theory of expected utility (articulated in terms of either "objective" or "subjective" probabilities) can accept. The more specific issue now under consideration, concerning whether rights trump utilitarian considerations, is raised and extensively discussed by Ronald Dworkin. See generally RONALD DWORKIN, TAKING RIGHTS SERIOUSLY (1977) (offering a theory of rights that allows the society to reap the benefits of a political democracy that enforces utilitarianism, while at the same time protecting fundamental rights of its citizens). Dworkin's own account, however, I find less than satisfactory, and this for reasons similar to those that I raised in connection with Nozick's account of rights. See supra note 50 (criticizing Nozick's take on the theory of natural rights). Dworkin presses upon us the claim that rights are trumps, but he offers little by way of argument for this relationship between rights and utilitarian considerations: it is simply presented to the reader as capturing our (his?) intuitions on the subject. 
son, it can hardly be taken, as many philosophers and even some economists have thought, as the fundamental principle for shaping social, political, and economic policies. ${ }^{87}$

\section{The Negative/Positive Distinction}

Much has been written about the significance of a particular distinction that can be drawn between two basic ways in which to deal with the risks to which individuals are exposed. This is the distinction between having persons simply refrain from acting in various ways, for example trespassing on the "territory" of others (however that is defined), and positively coordinating or cooperating with each other. Thus, for instance, protection from certain kinds of threats to personal bodily integrity-specifically, threats from other members of one's own society-can be achieved by simply having everyone constrain their own actions in various ways, by avoiding crossing the boundaries that are established between persons. ${ }^{88}$ What are marked

${ }^{87}$ The last few decades have witnessed two extraordinarily articulate and equally thoughtful presentations of the case against the conception of an unlimited scope for a utilitarian principle: one set forth by Ronald Dworkin and the other by John Rawls. DWORKIN, supra note 86; RAWLS, supra note 15 . To be sure, as many have read the debate that followed the publication of Rawls's work, there is something inconclusive about the argument from behind the veil of ignorance. And, again, while Dworkin's brief for a theory of rights that sets constraints on the operation of a utilitarian principle is powerfully advocated, still his own argument, as I have already suggested, supra note 12, makes altogether too much of an appeal to intuition. The line of reasoning I have pursued here, which is adapted from Buchanan and Tullock's argument in The Calculus of Consent, for a constitutional structure, offers a more secure route to the conclusion embraced by both Dworkin and Rawls. That is, it provides a ground for Dworkin's intuitions about rights by appeal to a theory of rational, prudential choice; and it offers a way to reconstruct Rawls's argument from behind the veil of ignorance so that, leaving to one side the question of whether it yields Rawls's own theory of justice, it still serves to effectively underline what he finds so worrisome about the utilitarian principle. For a more extended discussion of the shaky grounds on which the utilitarian principle is usually defended, see Edward F. McClennen, Utility and Utilitarianism, in VALUES, JUSTICE AND ECONOMICS (Gerald F. Gaus et al. eds., forthcoming 2003).

${ }_{88}$ The theme of mutual disengagement is central to Hobbes's classical analysis of what it means to lay down a right.

To lay down a man's right to anything is to divest himself of the liberty of hindering another of the benefit of his own right to the same. For he that renounceth or passeth away his right giveth not to any other man a right which he had not before, because there is nothing to which every man had not right by nature, but only standeth out of his way that he may enjoy his own original right without hinderance from him, not without hinderance from another. So that the effect which redoundeth to one man by another man's defect of 
in this way are what have come to be known as "negative" rights. By way of contrast, very little can be accomplished by way of protecting persons against acts of nature, except by concerted and elaborate coordination of efforts (i.e., to build dikes or dams, or to compensate by concerted public or private philanthropic effort). Similarly, safety nets cannot be provided by acts of omission, but only by an elaborate scheme involving what amounts to a redistribution of goods.

The negative/positive distinction is intelligible enough, but it is often introduced in the context of an impassioned defense, in terms of public arrangements, of "negative" rights (rights to noninterference) and rejection of "positive" rights (such as a right to a social minimum). ${ }^{89}$ In the first place, securing the members of a society from external aggression requires a huge "positive" coordination of effort. And even if internal order could be achieved, in principle, by each simply refraining from certain actions, still the maintenance of internal order - the assuring that others within one's own society will respect one's rights-requires a significant positive coordination of effort (by law enforcement officers). ${ }^{90}$

To treat "negative" rights as having some special status that does not extend to "positive" rights also has the effect of elevating the harms done by other people to a special status. But whatever level of security one desires with regard to losses that would impact on one's future ability to fulfill one's desires, there is no reason why one would want to have security with respect to aggressive actions of persons, but have no interest, or less interest, say, in protecting against losses deriving from acts of nature or the negative externalities generated by the social and economic actions of other individuals or groups. In very general terms, it cannot be the source of the risk, nor the nature of the activity required to reduce the risk, that determines whether the risk is one about which it is rational for persons to be prudentially concerned.

right is but so much diminution of impediments to the use of his own right original.

HOBBES, supra note 1 , at ch. xiv, para. 6.

${ }^{89}$ For a general discussion of the distinction between "negative" and "positive" rights, see HenRy SHue, BASIC Richts: SubsistenCE, AFFLUENCE, AND U.S. FOREIGN POLICY 35-64 (1980).

${ }^{90}$ To this, see the discussion in HOLMES \& SUNSTEIN, supra note 74 , at $37-43$. 


\section{Conclusion: SEcurity AND Mutual AdVANTAGE}

I have argued here that prudential concerns cannot be met by a system in which the level of protection is determined by political giveand-take. What inferences can we draw from this regarding societies in which this is the way that these matters are resolved? One obvious point here is that bargains regarding protection are not, in general, bargains over how high the level of protection will be set. They are typically also bargains that affect the distribution of protection as well. Those who are well off are able to secure in the marketplace the level of protection they desire, while those who are not well off have to settle for less. The question of prudence, then, inevitably becomes one of distribution. Insofar as matters are left to the usual political processes, the result will be that some are able to secure the protections they desire and others are not.

For the moment, I shall content myself with some closing comments about the more direct implications of a failure to address the prudential concerns of all members of society. Mutually beneficial cooperation can be seriously undercut by concern on the part of some participants that they lack an adequate assurance that their substantial prudential concerns will be respected. Without such an assurance, individuals will be disposed to seek less inclusive forms of association that will enable them to look out for themselves and others whom they care about and who are in the same predicament. This is likely to have three significant consequences: The first is that there are real economic opportunity costs involved in less inclusive forms of association and commercial exchange. The second is that there is likely to be an increase in social and economic conflict, and this will also have implications for how successfully the members of such a society can secure the gains that can come from effective cooperation. The third is that the failure to meet the prudential concerns of participants poses a special problem for any society that hopes to create a culture that can reap the benefits that come from respect for rules. ${ }^{91}$ Rational individuals whose prudential concerns are not met by the basic structure of society can hardly be supposed to have as strong a commitment to act in a principled fashion. They will see their relations to

For a discussion of the importance of our attitudes towards rules, see Edward F. McClennen, The Strategy of Cooperation, in PrACTICAL RATIONALITY AND PREFERENCE: ESSAYS FOR DAVID GAUTHIER 189 (Christopher W. Morris \& Arthur Ripstein eds., 2001). 
others shaped, not by mutually accepted principles, but by the distribution of force and power in society. Conformity to the rules defining the society will have to be secured, then, not by a mutual acceptance of shared rights and obligations, but by elaborate surveillance and enforcement mechanisms. And on any credible account, these mechanisms involve high costs that will have to be borne by the participants themselves. 
